\title{
Economic challenges facing Fiji before the storm
}

\author{
Biman C. Prasad
}

Fiji entered into a new era with the May 1999 general election under a Constitution which guaranteed equality to all its citizens. The real challenge for Fiji and its new government was to deliver the promised economic goods and services to its people. Economic prosperity and equality are the keys to creating a truly multiracial Fiji.

\section{Current economic policy environment}

Fiji seemed to be on its way out of the economic gloom of the last two years. The drought of 1998 leading to a 40 per cent reduction in sugar production and the 20 per cent devaluation of the Fiji dollar to enhance competitiveness due to the Asian financial crisis were some of the difficult situations to deal with. The positive factors are the expected rise in sugar production after the drought of 1998, low real interest rates, expansionary fiscal policies and the competitive exchange rate after the devaluation.

The Reserve Bank had forecast favourable conditions for sugar production, revising its estimate of 400,000 tonnes upwards to about 420,000 tonnes. It also forecast a strong performance in other sectors such as tourism, garment exports, forestry and fishing. Interest rates were continuing to decline, with the weighted average lending rate of commercial banks at 8.8 per cent in May 1999.

The Chaudhry government's 2000 budget forecast a growth rate of GDP of 7.8 per cent in 1999 up from the previous forecast of 7.4 per cent. The Reserve Bank of Fiji attributed this performance to strong growth in the forestry, building and mining industries. While these are positive factors, the negatives include the impending controversy regarding land leases and the performance of the sugar industry. The Reserve Bank, for example, points out that that the weather conditions have affected the cane quality and the total cane to sugar ratio has averaged 9.7 compared to 8.2 in 1998 (Reserve Bank of Fiji 1999). 


\begin{tabular}{lcc}
\hline Table 10.1 & Commercial banks' lending rates in selected sectors \\
Sectors & April $1998(\%)$ & April $1999(\%)$ \\
Agriculture & 10.45 & 9.59 \\
Manufacturing & 9.35 & 7.64 \\
Building and Construction & 9.75 & 8.85 \\
Real Estate & 10.17 & 9.03 \\
Private Individuals & 10.47 & 9.74 \\
Housing & 9.84 & 9.12 \\
All sectors & 9.93 & 8.89
\end{tabular}

Source: Reserve Bank of Fiji, 1999. News Review, 16( 6), Suva.

\section{Was the Chaudhry government setting a different economic policy agenda for Fiji?}

It was generally expected that the Chaudhry government would substantially change the economic policy direction of Fiji. The expectation arose largely from the criticisms leveled at the previous government's economic policy by the Fiji Labour Party (FLP). Before we analyse the budget, it is appropriate to briefly state the main thrust of the People's Coalition Manifesto.

The People's Coalition, comprising four political parties in government, had indicated a strong socialist agenda and the policies to be adopted by the government were clearly spelt out in the election manifesto. Some of the broad promises and statements were

- the government is committed to promoting strong economic growth to deliver its promises

- promotion of the rural and agricultural development and redevelopment of the rice industry

- enhancing tourism development by encouraging large scale foreign investment

- reverse privatisation of public enterprises

- reduce housing interest rates from 11 per cent to 6 per cent

- implementation of minimum wages of F\$120 per week

- removal of VAT from basic food items, medical charges and supplies, public transport; and essential educational materials

- increased public expenditure on health, education and social services, crime and other social ills.

The government's tax agenda was summarised in the People's Coalition Manifesto.

The People's Coalition recognises that taxation plays an important part in revenue collection and the distribution of wealth. However, the tax burden on ordinary people has been allowed to grow too large 
under the SVT government. We must provide incentives to reward individual effort, encourage people to save, invest, create employment and so generate growth in the economy (1999:14).

\section{Chaudhry government budget}

National budgets provide two things, first they are an indication of what the people can expect in the short term and what is to come in future. Second they are supposed to lay the foundation for the country's long term economic policy agenda. For the Chaudhry government, the 2000 budget was expected to do both, deliver the promises made and at the same time lay the agenda for long-term economic policy direction.

Fiji's budgets over the last decade have emphasised private sector-led development, and government policies were designed to pursue that. For example, in the 1999 budget the SVT government provided for the sale of public enterprises, further relaxed exchange controls and twenty year tax holidays for hotels with investments of more than F $\$ 40$ million, eliminated double taxation on company profits and provided a range of other benefits to potential investors. The 2000 budget did not reverse these concessions or policies, supporting the concessions provided by the SVT government. There was no change in the trade policies. This would have relieved private sector investors. The government included funding for research and development of new products for export which would have been welcomed by potential investors. However, the government should have realised that concessions to investors in the last 2-3 years have not produced the expected results and investment has remained sluggish. Since 1988 private sector investment has continued to decline; it has remained at less than 5 per cent of gross domestic product (GDP) since 1990. New initiatives and changes to policies were not considered to attract private investment. There were no statements on new projects like the Namosi Copper mine and other private sector initiatives to attract new investment into the natural resources-based sector.

The 1999 budget had a number of measures that benefited low-income earners. These included increases in the income tax threshold from $\mathrm{F} \$ 5,000$ to $F \$ 6,500$, increases in dependent child allowance, widowed persons allowance and increases in Fiji National Provident Fund (FNPF) and insurance allowance. What did the Coalition's 2000 budget have? It continued in the same direction by increasing spouse tax allowance from $F \$ 1,000$ to $F \$ 1,200$, child tax allowance and FNPF allowance. But these increases will not help those on lower incomes, they will largely benefit middle and high-income earners. Those earning below $\mathrm{F} \$ 6,500$ are not paying taxes anyway. The positives of the budget and its implication for the poor are not surprising. Judging by the People's Coalition manifesto, 
the provisions in the budget fell far short of what was promised. The government answered critics wanting to know where the money would come from, by not delivering too much and thereby containing the deficit. However, it could be excused for not delivering all its promises in this budget-in fact it never intended to do so when the promises were made. After all they thought they had at least another four budgets to deliver on their promises. The increases in the budget allocation to the Health, Education and Social Welfare ministries are welcomed. These are positive moves that would benefit the poor and the economy in the long-run. However, on the expenditure side and reallocation, government has continued with the allocation of unproductive expenditure-it makes little sense to increase expenditure for the army by F\$6 million dollars while the police department receives only an extra $\mathrm{F} \$ 1$ million. Is this enough given the importance of reducing crime, corruption and having good governance? The Social Welfare department, on the other hand received an increase of only $\mathrm{F} \$ 3.3$ million.

On the revenue side there seems to be an assumption that tax compliance will make up for the shortfall in income tax revenue from the collection of value-added tax (VAT). For example the estimates show that VAT revenue is estimated to only decline by $\mathrm{F} \$ 7.6$ million, and that income tax revenue will increase by about $\mathrm{F} \$ 15$ million dollars. Furthermore, there were hopes to raise an extra F\$9.6 million from dividends on government capital investment. These are strong assumptions in an area of revenue collection and one has to be wary of these.

The Chaudhry government continued with a policy of financial liberalisation and the progressive relaxation of the exchange controls, building on the significant relaxation announced by the Soqosoqo $\mathrm{ni}$ Vakavulewa ni Taukei (SVT) government. With regard to the financial services reform, the government announced the establishment of the Banking Commission and the Banking Ombudsman. This was a healthy development which should have been welcomed by the consumers.

Low wages and lack of employment is the biggest cause of poverty in Fiji. The government's decision to remove VAT from essential services was laudable, but it did not go far enough towards addressing the problem of real poverty. The interim government led by Ratu Sir Kamisese Mara implemented a VAT of 10 per cent in 1991. This was seen by many as a regressive tax as indeed many indirect taxes are. The VAT was implemented in the absence of parliament and without much debate-one of the reasons why it was seen as politically irresponsible. The concern that the poor would be most affected was to some extent mitigated by the allocation of funds for poverty alleviation. While it cannot be denied that the VAT had an initial adverse impact on the poor, its revenue potential and contribution 
to government finances has been very significant. After an initial decline, government revenue remained above 25 per cent of total GDP, and increased slightly in 1996 and 1997.

After the general elections in 1992, the Fiji Labour Party (FLP) supported the coup leader becoming Prime Minister. One of the conditions for such support was the total removal of VAT. However, that position changed with the coalition government announcing the removal of VAT from basic food items, medical charges and supplies, public transport and essential educational materials.

A VAT was introduced largely to increase the tax base and provide some administrative ease in collecting them. It was designed to bring a larger number of people into the tax net. From the income distribution point of view, the VAT has been a regressive tax which is why the Chaudhry government reduced it on essential items. When VAT zero-rates a number of essential goods and services, and taxes luxury goods the tax may become progressive. However, the administrative cost of doing this could be enormous, and could create further distortions from an economic efficiency point of view. In Fiji, where there is already a problem of proper compliance, exemption of some goods could create further compliance problems. In some developed countries social security adjustments have been considered to take into account those at lower income levels. The government was also considering reducing the across-the-board VAT of 10 per cent to a lower level to reduce administrative and compliance problems, which may also be economically efficient.

Over 70 per cent of the people in Fiji earn less than F\$6,000 dollars-on a weekly basis this is less than the minimum wage of F\$120 dollars per week. The majority of people in the lower income bracket earn less than F\$100 dollars a week. The Chaudhry government missed a golden opportunity to announce definite measures to bring about a national minimum wage which would have helped thousands of lower paid workers. Instead only small benefits are being derived through the reduction in prices brought about by the removal of VAT on essential items.

The situation with regards to employment in Fiji is serious. Official estimates point out that there are 15,000 school leavers who enter the market every year in search for jobs. Of these, 5,100 are females and 9,900 males. The minimum qualification of the majority of these school leavers is the Fiji School Leaving Certificate which does not equip the person with the appropriate skills to enter the job market easily. A part from school leavers, there are another 2,000 persons entering the job market every year. These include about 500 females and 300 youths who have no formal qualifications, and about 1,200 who are the victims of downsizing in the government sector and the laying-off of workers by commercial enterprises. 
A total of 17,000 unemployed persons per year are looking for employment. The Chaudhry government's claim it would create 9,000 jobs was an overly optimistic projection.

In terms of changes to taxation policies, the opportunity went begging. The Chaudhry government didn't make any statements on reviewing or changing income tax, which is not as progressive as it should be. There was no statement on company taxes, capital gains tax, nor on estate and gift duties. It was expected that rather than political procrastination the government would at least consider these aspects of the taxation systemthey are the ones that would ultimately provide the incentives and mechanism for redistribution of wealth.

The People's Coalition had indicated that a capital gains tax might be implemented. From the equity and social point of view this tax may be desirable. In the case of Fiji this may bring popular accolade from some sections of the electorate, at a potentially inappropriate time and it could be inimical to economic growth. What Fiji needs is investment from the private sector, and a capital gains tax may not provide the right incentives. I believe that anticipation of the tax itself led to the consumption and flight of capital. Tax revenue amounts to about 82 per cent of the total revenue for the Fijian government (see Table 10.2). Tax policies are sensitive economic issues and the review of the existing tax policies, if not done carefully, can provide the wrong signals for potential investors.

An increase of F $\$ 10$ million in the Agriculture budget was a step in the right direction, and efforts to support diversification and marketing of agricultural products should be the key agricultural policy for the future.

\begin{tabular}{|c|c|c|c|c|c|c|}
\hline \multirow{2}{*}{$\begin{array}{l}\text { Table } 10.2 \\
\text { Year }\end{array}$} & \multicolumn{4}{|c|}{ Sources of Fiji government revenue, 1991-98 } & \multirow[b]{2}{*}{ Grants } & \multirow[b]{2}{*}{$\begin{array}{c}\text { Total } \\
\text { revenue } \\
\text { and grants }\end{array}$} \\
\hline & $\begin{array}{c}\text { Customs } \\
\text { excise }\end{array}$ & $\begin{array}{l}\text { Inland } \\
\text { revenue }\end{array}$ & $\begin{array}{l}\text { Non-tax } \\
\text { revenue }\end{array}$ & $\begin{array}{l}\text { Capital } \\
\text { revenue }\end{array}$ & & \\
\hline 1991 & 220.1 & 229.2 & 114.5 & 5.4 & 7.3 & 576.5 \\
\hline 1992 & 198.3 & 284.4 & 106.3 & 6.3 & 7.2 & 602.5 \\
\hline 1993 & 179.0 & 340.6 & 126.2 & 4.2 & 4.1 & 654.1 \\
\hline 1994 & 190.3 & 375.5 & 123.2 & 4.3 & 4.5 & 697.8 \\
\hline 1995 & 207.3 & 395.1 & 103.6 & 6.7 & 6.3 & 719.0 \\
\hline 1996 & 203.8 & 417.9 & 108.0 & 6.3 & 7.3 & 743.3 \\
\hline 1997 & 219.6 & 445.2 & 129.3 & 4.4 & 4.9 & 803.4 \\
\hline \multicolumn{7}{|l|}{1998} \\
\hline March & 49.8 & 87.8 & 19.8 & 0.7 & 0.6 & 158.7 \\
\hline June & 51.8 & 111.0 & 40.1 & 26.4 & 0.9 & 230.2 \\
\hline September & 59.6 & 144.9 & 27.3 & 0.4 & 0.5 & 232.7 \\
\hline
\end{tabular}


The SVT government managed to reduce the deficit to as low as 1.6 and 0.5 per cent of the GDP through strong revenue from tax. However, unexpected commitments such as the bailing out of the National Bank of Fiji, led to an increase in the deficit in 1996 and 1997 and a projected decrease in 1998 and 1999. The Coalition's 2000 budget maintained that trend, recognising that a small deficit is an important impetus for economic growth.

\section{Trade and investment policies}

Trade and investment policies will be the key to Fiji's economic growth. The Coalition government's position was to encourage trade and investment. However, it is important to point out that Fiji's economic reform agenda for the last ten years has been to move away from a largely importsubstitution policy direction to a export-oriented market economy. The economic reform agenda for the last ten years has included

- trade deregulation

- taxation reforms

- labour market reforms

- reduction in the size and management role of government

- public enterprises reform and

- moblisation of all sectors of the community in support of economic expansion.

Trade deregulation was designed to increase competition and encourage investment in sectors where Fiji had a competitive edge; for example, the garment industries. As part of these policies barriers to trade such as tariffs were reduced gradually. The labour market also underwent reforms. The expectation that the overall direction of economic policies would change substantially was not delivered in the Coalition's 2000 budget. The overall policy direction was maintained. The challenge for a new government is to balance these policies with both the changing world market conditions and its promises to the electorate. Fiji's exports increased between 1995 and 1996, but declined dramatically in 1997 and 1998, while imports continued to increase (Figure 10.1).

Private investment seems to be the key factor in the economic growth in Fiji in the long run. However, the level of private investment has remained weak at below 5 per cent of the GDP since 1992. Public sector investment, while strong between 1993 and 1995, has declined since 1996. Therefore, the total level of investment in the country has declined over the last few years. Figure 10.2 provides the trend in investment levels in Fiji since 1970.

The construction sector has also been relatively weak. This can also be attributed to low private sector investment. There is however, potential for growth in the construction sector if work on some of the up-market hotel facilities continues. 


\section{Role and size of government}

The basic philosophy of the coalition government was that the role of the government in managing the economy must also include the provision of essential services. It also believed that the government must actively pursue policies for the redistribution of wealth in the country through deliberate fiscal policies. One of the platforms on which the Chaudhry government was elected included the reduction in waste and proper management of the state's resources. This was not realised.

In Fiji, the relative size of government to GDP has been a major issue. The Rabuka government relied heavily on borrowing and ran a deficit budget of more than 5 per cent of the GDP. The rationale behind the reduction in the size of government has been to free up resources for growth in the private sector. Whilst the SVT government's stated objective was to reduce the size of government, its progress towards that goal was less promising. The composition of the total expenditure has been moving towards more consumption-related operating expenditure (see Figure 10.3). Productive capital investment expenditure has remained relatively weak in the last 8 years.

Table 10.3 Fiji's net budget deficit as a percentage of GDP

$\begin{array}{lccccc}\text { Year } & 1996 & 1997 & 1998 & 1999 & 2000 \\ \% \text { of GDP } & 5.2 & 9.2 & 2.8 & 2.3 & 1.9\end{array}$

Source: Ministry of Finance, 2000. Supplementary to the 2000 Budget: Fiji Government budget 2000, Ministry of Finance, Suva.

Figure 10.1 Fiji's merchandise exports and imports, 1991-97

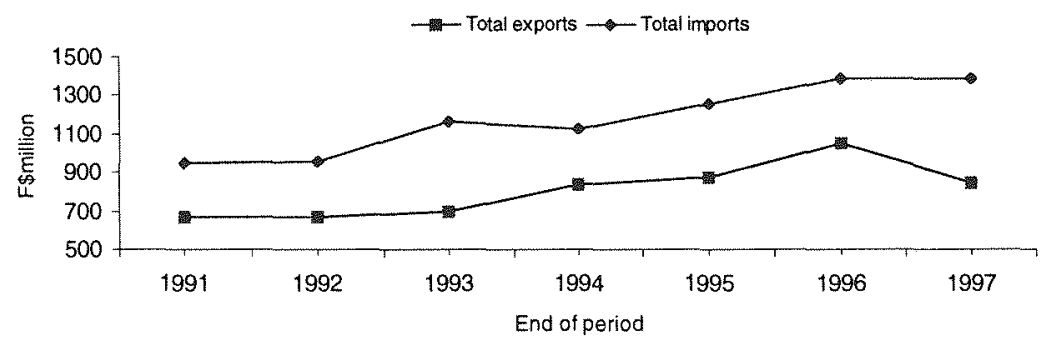

Source: Reserve Bank of Fiji, 1999. Quarterly Bulletin, March, Suva: Tables 31and 32. 
Total expenditure as a percentage of GDP has declined from 35.5 per cent in 1991 to 30.9 per cent in 1995. This trend has continued. While total revenue has continued to increase the total debt has also increased. The breakdown of the total debt shows that while external debt has not increased too much, domestic debt has continued to increase in the last few years (Table 10.4).

The SVT government had undertaken deliberate policies to do away with losses of $\mathrm{F} \$ 11$ million dollars per year through its public enterprises, undertaking major reform of public enterprises. These reforms included the corporatisation and privatisation. The Labour Party and the trade union movement in Fiji opposed many of these reforms. One the main issues in the opposition to these reforms was the subsequent job losses and the increase in the cost of services. The government owns 31 commercially oriented public enterprises with a total equity exceeding $\mathrm{F} \$ 600$ million (Government of Fiji 1997). A previous government policy was to slowly privatise these enterprises, for example selling shares in Fiji's national airline

The Chaudhry government had a platform intended to reverse the process of privatisation and corporatisation. It believed that public utilities such as water, electricity, telecommunications and civil aviation facilities must remain in public hands. As a matter of priority it reversed the reforms instituted in the Civil Aviation Authority and Fiji Electricity, but continued to sell government shares, hoping to raise revenue and selectively pursuing the process of privatisation. The issue with regards to corporatisation and privatisation is that there are enterprises which have not been profitable for many years, draining the public purse, but there are others which have been very profitable and could contribute to government revenue. However, the SVT government did not make that distinction and sold shares in

Figure 10.2 Investment level in Fiji, 1970-98

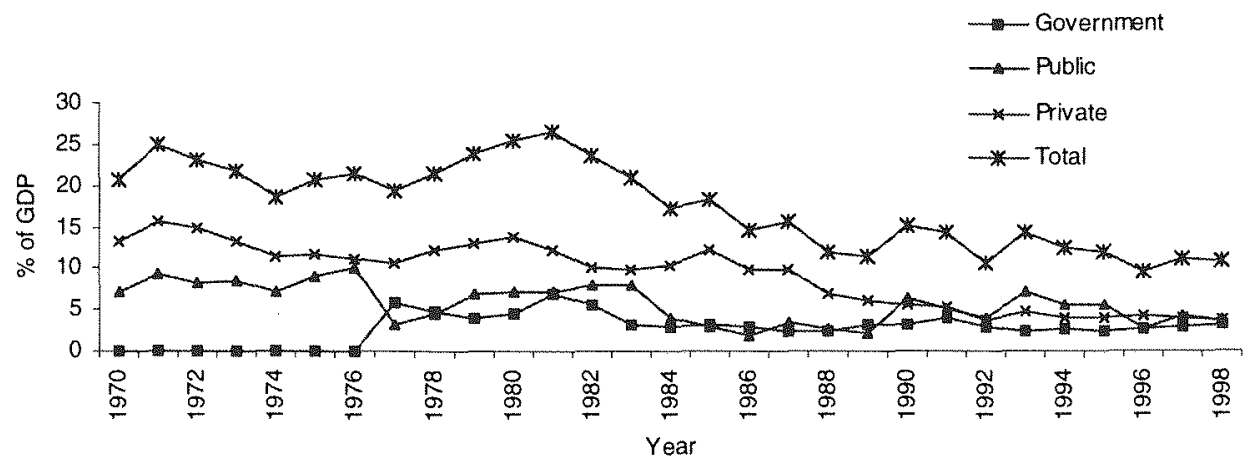

Source: Reserve Bank of Fiji, 1999. Quarterly Bulletin, March, Suva: Table 21. 
enterprises which were making profits. The new government will have to strike the right balance in its approach to the management of public enterprises.

\section{Other challenges}

One of the key obstacles to the performance of the Fijian economy has been the uncertainty of property rights to land in Fiji. There is no doubt that this uncertainty has affected production and efficiency in both the agriculture and the tourism sectors (Prasad and Tisdell 1996). Under the Agricultural Landlord and Tenant Act (ALTA), native land leases had been granted to tenants for 30 years. The legislation provided the mechanisms through which rent was determined and the relationship between tenants and landlords have been regulated. However since 1997 the land leases have begun to expire. Over the last few years a lot of uncertainty has been created in the minds of the tenants, causing a decline in productivity and efficiency. Landowners have been demanding compensation for public

Figure 10.3 Fiji government's expenditure, 1991-97

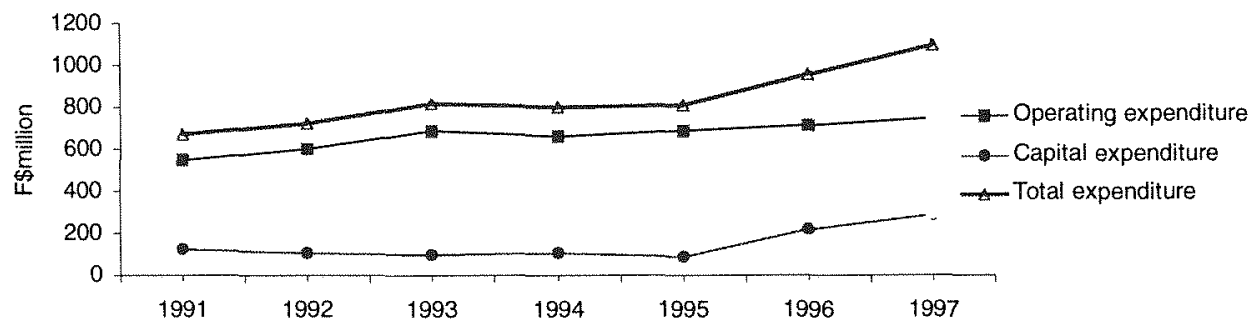

Source: Reserve Bank of Fiji, 1999. Quarterly Bulletin, March, Suva.

\begin{tabular}{lcc}
\hline Table 10.4 & \multicolumn{2}{c}{ Fiji's total external and domestic debt (F\$million) } \\
Year & External debt & Domestic debt \\
1992 & 499.07 & 638.2 \\
1993 & 449.98 & 733.5 \\
1994 & 399.17 & 792.3 \\
1995 & 384.70 & 807.3 \\
1996 & 353.64 & 942.8 \\
1997 & 352.11 & $1,156.0$ \\
1998 & 394.29 & $1,060.6$
\end{tabular}

Source: Reserve Bank of Fiji, 1999. Quarterly Bulletin, March, Suva: Tables 25 and 26. 
infrastructure on native land and government will have to deal with more of this in the future.

The resolution of the ALTA legislation and the provision for the renewal of the leases is now an immediate priority for the government. Apart from the uncertainty in the farming sector, other sectors such as investment in fisheries development, forestry and tourism are also waiting for a satisfactory resolution to this issue.

The allocation for the ALTA tenant's resettlement and compensation of F $\$ 20$ million is inadequate in view of the number of leases that are expiring. In 2000 about 1,828 farm leases will expire, of which 1,215 are sugar cane farm leases. If we take all the farm leases and multiply that by the planned F $\$ 28,000$ compensation, or cost of resettlement, then government would have to budget for about F\$51.184 million for 2000 alone. However, if government were to provide $\mathrm{F} \$ 28,000$ to just the cane farmers, it would still cost $F \$ 34.2$ million. One can reduce this further by taking away 25 per cent of the leases occupied by indigenous Fijian tenants, but still it would cost F $\$ 25.536$ million in 2000 to provide compensation to the cane farmers that would have lost their leases. Furthermore, the amount of F\$28,000 is the cost of resettlement of the tenants, it does not compensate the tenants for the improvements, building and other farm implements which may attract very low market prices.

Fiji's sugar industry is passing through a critical period. First, there is insecurity of land tenure and the threat of non-renewal of leases after 1997. Second is the exposure of the industry to the changing global economic conditions. Currently the bulk of Fiji's sugar is sold under the Lomé Convention. This provides preferential arrangements for Fiji's sugar to be sold at more than the world market price in the European Union (EU). With the increasing globalisation of the world economy and the successful conclusion of the GATT, prices received for Fiji's sugar may not be sustainable in the long-run.

These circumstances have called for reforms within the sugar industry. With the increasing surge towards freer trade worldwide, the EU preferential price for Fiji sugar may end sooner rather than later. Reforms in the industry cannot proceed without a solution to the property rights structure in land. Reforms to increase efficiency and productivity without corresponding reforms in the system of land tenure are unlikely to yield the desired results.

Productivity in the sugar industry depends on many factors such as production cost, milling efficiency, availability of labour and fertiliser input. Increasing farmer indebtedness is also affecting investments in productivity. While these factors are an important consideration, the overwhelming concern of the farmers is about the tenure of their leases. So long as the lease question hangs in the balance any reform process designed to increase 
productivity could be counterproductive. The major concern of the tenants is the insecurity of their tenure and that the renewal of the leases will involve much higher rents. Table 10.5 shows the number of leases that expire in each year from 1997 to 2005.

After the adoption of the 1997 Constitution, the then prime minister and the leader of the Opposition worked towards setting up a committee which was in the process of working out the best possible arrangement to resolve the native land lease problems. The SVT government, in consultation with the Native Land Trust Board (NLTB), had agreed to renew about 90 per cent of the leases and out of 134 expiring leases, 104 had already been renewed.

The Chaudhry government opened up another controversial debate on the issue of converting state lands to native land. This issue is not new, but it did not have public support, nor has it had support in parliament since the 1950s. The state only owns 10 per cent of the land in Fiji, so it was considered that in the interest of good governance this land should remain under government control. The Chaudhry government tabled a Bill in parliament seeking the conversion of Crown schedule A and B land. It is yet to be debated. This in my view created more uncertainty in the minds of the tenant community and could potentially open up native title claims for the freehold land. The attempt to convert state land is not a new move, but when it was tried before it was found that there were no compelling reasons to do so. For example, the Burns Commission said '[t]here is no moral or legal reason why government should give up control of schedule $A$ and $B$ land which should be held in trust for the benefit of the colony as a whole for leasing or otherwise' (Legislative Council: Paper No.1).

Table 10.5 Expiration of agricultural farm and cane leases in Fiji, 1997-2005

$\begin{array}{ccc}\text { Year } & \text { No. of farm leases } & \text { No. of cane leases } \\ 1997 & 45 & 26 \\ 1998 & 189 & 129 \\ 1999 & 231 & 168 \\ 2000 & 1,828 & 1,215 \\ 2001 & 1,808 & 1,536 \\ 2002 & 479 & 325 \\ 2003 & 645 & 466 \\ 2004 & 332 & 231 \\ 2005 & 288 & 244\end{array}$

Source: World Bank, 1995. Fiji: restoring growth in a changing global environment, The World Bank, Washington, DC. 
The situation in Fiji is not comparable to Australia and New Zealand where the majority of the land is freehold. In Fiji 83 per cent of land is owned under native title.

The challenge for a new government will be to create a climate conducive to continuing the negotiations for a satisfactory resolution of the land lease problem. The Chaudhry government proposed to establish a land use commission to identify unused land. Inevitably, government has to allocate extra resources if the majority of the land leases are not renewed. This will put further strain on the budget.

\section{Conclusions}

The Chaudhry government's orientation towards a strong social agenda was laudable. However, its 2000 budget pointed to the fact that its economic policy direction did not change too radically after all. This may have been realistic given the world economic policy environment and the dependence of the Fijian economy on its main trading partners, Australia, New Zealand and the United States. The Chaudhry government may just have been a capitalist government in a socialist garb, like many Labour governments in other parts of the world.

Economic growth is the key to the delivery of promised social services. And for economic growth to occur the Fiji's government will have to promote the private sector as the engine of growth, since public sector expenditure will be limited given the country's current financial position. However, government should not shy away from some fundamental changes that may put Fiji in a better position as a small island country to endure the forces of global capitalism.

The issues that would need to be considered carefully for sustained levels of growth include the following

- consistent investment policy with appropriate incentives for the private sector

- competitive and productive labour force

- development of appropriate public infrastructure

- satisfactory resolution of the property rights in land generally and the more specifically the resolution of expiring native land leases under ALTA

- sound monetary and exchange rate policy to ensure that Fiji's exports are competitive in the world market

- competitive and productive labour market

- stability in government and a reduction in the crime rate.

Those who believed that Fiji's economic policy direction would change remarkably will be disappointed with the Chaudhry government's missed opportunity to implement policies that would have sent the right signals 
to the world economic community, the World Trade Organization and international organisations such as the International Monetary Fund and the World Bank-that countries can steer their own economic agenda and not fall into the global trap of world trade. In this sense the Chaudhry government's 2000 budget was no different; it continued with the policies of deregulation, financial liberalisation, free trade policy and disguised privatisation. For example, it continued to support limited privatisation hoping to make $\mathrm{F} \$ 70$ million from the sale of government shares, it suggested contracting out public services to private companies, it continued the policy of deregulation and it failed to consider changes in the taxation system which would have further led to the redistribution of wealth. There was hardly any change in overall economic policy direction, which is regrettable. It was the same old song, with a slightly different tune.

\section{Note}

An earlier version of this paper was presented at the Samoa and Fiji Focus, in association with the Centre for the Contemporary Pacific, The Australian National University and Economic Insights, Brisbane, 9 July 1999. 